\title{
PROPOSALS TO CURTAIL FEDERAL HABEAS CORPUS FOR STATE PRISONERS: COLLATERAL ATTACK ON THE GREAT WRIT
}

\author{
LOUIS H. POLLAK $\dagger$
}

\begin{abstract}
"We propose now to show this committee by illustrative cases what happens when Federal courts intervene in behalf of prisoners convicted in State courts by means of Federal habeas corpus. There are literally hundreds of cases from all States, and we can only select a few."

"....

"In one respect this [Leyra v. Denno] is the most significant case of all that we have discussed in that it shows how a case can be tried in the State courts, going all the way to the highest Appellate Court of New York, a new trial granted, the case tried again, and appealed to the Appellate Court of the State of New York, and affirmed. All State remedies having been exhausted and the case having been fully tried in all the courts of the State of New York, with certiorari denied by the Supreme Court of the United States, Leyra then sued out a petition for writ of habeas corpus in one of the United States district courts of New York, and the case then went the full routine of Federal hearings through the circuit court of appeals to the Supreme Court of the United States. The outstanding significance of this case is that it shows and clearly demonstrates that the same questions can be litigated fully in all the courts of the State, the petitioner can then ask the Supreme Court of the United States for certiorari to pass on these same questions, and the Supreme Court of the United States refuses the application for certiorari. The identical questions (competency of confession) have been litigated through all the Federal courts and the Supreme Court of the United States then grants certiorari, although it had previously refused to do so when the matter was going through the State courts and on the same question of confessions; the certiorari, however, is granted when the case comes through the Federal courts on the same question of confessions, and the Supreme Court of the United States then reverses the case and orders another trial. We do not know the final disposition of the case...."
\end{abstract}

\section{The Probleni}

THe quoted indictment of the tedious proceedings in Leyra $v$. Denno ${ }^{2}$ is part of a long memorandum submitted by Ralph Moody, Assistant Attorney General of North Carolina, to the Judiciary Committee of the House of Representatives

$\dagger$ Associate Professor of Law, Yale Law School.

The author wishes to acknowledge the invaluable assistance of Louise E. Farr, Research Associate, Yale Law School.

1. Excerpts from Statement of Ralph Moody, Assistant Attorney General of North Carolina, in Support of H.R. 5649, Hearings on H.R. 5649 before Subcommittee No. 3 of the House Committee on the Judiciary, 84th Cong., 1st Sess. at 45, 51 (1955) (hereinafter cited as Hearings).

2. 347 U.S. 556 (1954). 
on June 24, 1955. Mr. Moody submitted the memorandum on behalf of the National Association of Attorneys General in support of a then pending bill designed to curtail the jurisdiction of federal courts to inquire, on habeas corpus, into the propriety of state court criminal convictions. The specific legislative proposal, H.R. 5649,3 passed the House of Representatives but died in the Senate Judiciary Committee when the Eighty-fourth Congress, on July 27, 1956 , adjourned sine die. But the problem troubling Mr. Moody and his colleagues did not die with the bill. In all likelihood the next Congress will be confronted with similar legislation. Mr. Moody's quarrel with the existing latitude of federal habeas corpus poses issues demanding the devoted attention of those concerned with the smooth functioning of the federal system. Yet the issues are not new-they are as old as the Constitution.

It is familiar history that the Constitutional Convention, after vigorous and prescient debate, recognized that the new national government, superimposed on pre-existing states jealous of their sovereignty, must be endowed with power to establish its own judicial system-a system necessarily overlapping the functions of the existing state courts. It was, to be sure, the plain intent of the framers that Congress should "make use of the State Tribunals whenever it could be done, with safety to the general interest." 4 But emphasis on the desirability of restraint in establishing federal jurisdiction only underscored the fact that concurrent judicial power portended conflict-and conflict under the supremacy clause could in the last analysis only mean that the national tribunals would have ultimate revisory power.

Transforming this theoretical imperative of revisory power into reality could not have been easy in any event; but it necessarily provoked profoundest parochial antagonism in criminal cases. When the Supreme Court issued its writ of error to review Corn Tassel's death sentence, the Georgia authorities showed their sovereign contempt for the Court's process by executing the defendant and thereby effectively mooting his appeal. ${ }^{5}$ But that was in 1830-only fourteen years after Justice Story, reversing a recalcitrant Virginia Court of Appeals, indelibly blueprinted the Supreme Court's power to overturn judgments of state courts, ${ }^{6}$ and a scant nine years after Chief Justice Marshall first asserted the Supreme Court's power to review a state criminal conviction. ${ }^{7}$ Today, although Georgia and Virginia mutter threats of "interposition" against

3. S4th Cong., 1st Sess. (1955).

The bill is set forth verbatim in the text at p. 57 infra.

4. The language is that of Roger Sherman, advocating the successful compromise that gave Congress discretion to establish federal courts inferior to the Supreme Court. See 2 Farrand, The Records of the Federal Convention $45-46$ (1911).

5. Warren, Legislative and Judicial Attacks on the Supreme Court of the United States-A History of the Twenty-fifth Section of the Judiciary Act, 47 Am. L. Rev. 161, 167 (1913).

6. Martin v. Hunter's Lessee, 14 U.S. (1 Wheat.) $* 304$ (1816).

7. Cohens v. Virginia, 19 U.S. (6 Wheat.) *264 (1821) (motion to dismiss writ of error overruled; conviction then affirmed on merits). 
Supreme Court decisions in other fields, ${ }^{8}$ no serious question is raised about the Court's appellate authority to set aside state criminal convictions secured in violation of federally protected rights.

The question vexing Mr. Moody-and currently besetting judges, legislators, prosecutors and convicts-is the propriety and scope of an alternative and allegedly less palatable form of federal intervention : federal district court jurisdiction to make collateral inquiry into state court criminal convictions. Since 1867 , the so-called "inferior" federal courts have been empowered, on habeas corpus, to reopen "all cases where any person may be restrained of his or her liberty in violation of the Constitution, or of any treaty or law of the United States. ..." Initially, this auxiliary form of federal inquiry was only a minor nuisance to state authorities, since conventionally the state's burden on habeas corpus was merely to show that the state court was one of competent jurisdiction. ${ }^{10}$ Gradually, however, the federal inquiry on habeas corpus has widened. The federal judge's job, the Supreme Court announced in 1915, was "to look beyond forms and inquire into the very substance of the matter, to the extent of deciding whether the prisoner has been deprived of his liberty without due process of law. ..."11 This formula, coupled with latter-day judicial amplification of the content of "due process of law," laid the basis for what has now become a substantial volume of habeas corpus applications from state prisoners serving jail terms or awaiting execution.

Typically, the applicant will urge that the state trial was fatally tainted by lack of counsel, ${ }^{12}$ by a coerced confession, ${ }^{13}$ by officially suborned perjury, ${ }^{14}$ by discriminatory jury selection, ${ }^{15}$ or by other deprivations of Fourteenth Amendment rights. ${ }^{16}$ If (1) the moving papers adequately set forth facts rais-

8. See Georgia House Resolution No. 185, 1 Race Relations L. REP. 438 (1956), and Virginia Senate Joint Resolution No. 3, 1 RACE RELATrons L. REP. 445 (1956), both directed at the Supreme Court's decisions in the School Segregation Cases, 347 U.S. 483, 497 (1954), and 349 U.S. 294 (1955).

9. Act of February 5, 1867, 14 STAT. 385. The statutory language has been altered in detail but not in substance. 28 U.S.C. $\$ 2241(3)$ (1952) ; cf. 28 U.S.C. $\S 2254$ (1952).

The Habeas Corpus Act of 1867 was passed some months after Congress proposed the Fourteenth Amendment to the states but over a year before the ratification process was completed. The act was plainly intended to help safeguard the new statutory and constitutional rights created after the Civil War. See Note, The Freedon Writ-The Expanded Use of Federal Habeas Corpus, 61 HaRv. L. Rev. 657, 659 (1948).

10. See, e.g., Ex parte Bridges, 4 Fed. Cas. No. 1862, at 106 (C.C.N.D. Ga. 1875).

11. Frank v. Mangum, 237 U.S. 309, 331 (1915); see Moore v. Dempsey, 261 U.S. 86 (1923).

12. Wade v. Mayo, 334 U.S. 672 (1948); House v. Mayo, 324 U.S. 42 (1945).

13. Leyra v. Denno, 347 U.S. 556 (1954).

14. Ex parte Hawk, 321 U.S. 114, 115-16 (1944); Mooney v. Holohan, 294 U.S. 103 (1935).

15. Brown v. Allen, 344 U.S. 443 (1953).

16. Louisiana ex rel. Francis v. Resweber, 329 U.S. 459 (1947) (double jeopardy and cruel and unusual punishment); Cochran v. Kansas, 316 U.S. 255 (1942) (suppression by prison officials of appeals documents); Frank v. Mangum, 237 U.S. 309 (1915) (mob 
ing substantial federal questions, (2) the applicant (a) has raised the federal questions in a state proceeding and has unsuccessfully sought certiorari from the adverse state judgment, ${ }^{17}$ or (b) has no available avenue of effective state collateral attack, ${ }^{18}$ and (3) the federal questions are ones not litigated by a federal court on a prior application for habeas corpus, ${ }^{19}$ the district court must hear and determine the issues presented.

From July 1940 through June 1941-what may be regarded as the year of transition from the "old" to the "new" Supreme Court-federal district courts received 127 applications for habeas corpus from persons in state custody. ${ }^{20}$ In 1955, after fifteen years of heightened Supreme Court insistence on fair criminal procedures, the volume of applications had increased over five-foldto $660 .{ }^{21}$ But the percentage of applications in which relief was granted was never large and has not risen. On the contrary-in 1946 (when applications were at about the 500 mark) only 2.8 per cent of the applications had some measure of success, and by 1954 even that figure had shrunk to 1.3 per cent. ${ }^{22}$ Indeed, the proportion of applicants whom the federal courts finally order discharged from state custody probably does not exceed the miniscule figure of .15 per cent-about one applicant per year. ${ }^{23}$ Moreover-and this tellingly underscores the insufficiency of the average application-from 1941 to 1954 only 7.3 per cent of the cases reached the hearing stage, and in the past few years this latter figure has fallen to about 4 per cent. ${ }^{24}$

It has not been hard to infer from statistics of this kind "that literally hundreds and thousands of phoney habeas corpus proceedings ... now clutter up and confuse an already overcrowded federal docket. . .."2s Acceptance of this conclusion has led not unnaturally to the view that current habeas corpus practice squanders the energies and budgets of federal courts and state law enforcement officials. It accomplishes nothing, so it is urged, except educating idle convicts in the niceties of criminal procedure and delaying society's rightful day of retribution in capital cases like Leyra $v$. Denno. ${ }^{26}$

domination of trial). See, generally, Note, Federal Habeas Corpus for State Prisoners, 55 Colun. L. Rev. 196 (1955).

17. Darr v. Burford, 339 U.S. 200 (1950), construing 28 U.S.C. $\$ 2254$ (1952).

1S. 28 U.S.C. $\$ 2254$ (1952).

19. 28 U.S.C. $\$ 2244$ (1952).

20. Hearings 24, Table 1. The statistics are the product of studies of habeas corpus litigation by the Administrative Office of the United States Courts.

21. Director of the Adainistrative Office of the Unimed States Courts, Ann. REP. 1955, at 169, Table C 3 (1956).

22. Hearings 25 , Table 3 .

23. See the comprehensive discussion of habeas corpus practice contained in Justice Frankfurter's separate opinion in Brown v. Allen, 344 U.S. 443, 498 (1953) ; this opinion, to which several references are hereafter made under the designation "separate opinion," is to be distinguished from the dissent on the merits filed by Justice Frankfurter in the same case and companion cases. 344 U.S. at 554.

24. Hearings 24 , Table 2 .

25. 102 CoNG. Rec. 801-02 (daily ed. Jan. 19, 1956).

26. 347 U.S. 556 (1954); see text at note 1 supra and notes 56-66 infra. 
Reenforcing these pragmatic considerations is the notion that there is some constitutional imbalance about a procedure that permits federal trial courts to review state appellate courts. In the considered view of the Conference of State Chief Justices, "Orderly Federal procedure under our dual system of Government should require that a final judgment of a State's highest court be subject to review or reversal only by the Supreme Court of the United States."27 And many federal judges appear to acquiesce in this view: "[O]ur sphere of superintendence should not extend to state police activities; there the state courts should have the burden, subject only to certiorari in the Supreme Court in the few cases where needed."28

In brief, then, critics of current habeas corpus practice have drawn two conclusions :

"[U]nder the expanded concept of the use of the writ, the dockets of the Federal district courts [have] become clogged with thousands of groundless, if not fraudulent claims. . ..."29

"[It] seems incongruous, when viewed in the light of the United States Constitution, to have the actions of our highest State courts reviewed by our lower Federal district courts, for it was never the intention of our Founding Fathers, in writing that Constitution, to have the writ of habeas corpus used as a writ of review by the lower Federal courts to review State court actions."30

Each conclusion seems suspect:

As to the first, there is every reason to suppose that a large proportion of the allegedly "frivolous" habeas corpus cases are merely testimonials to the difficulties of proof encountered in reconstructing trials long since forgotten. Even the most competent and best compensated lawyer faces enormous odds in piecing together inadequate trial transcripts and in gleaning the truth from memories of judges, clerks and prosecutors whose own past conduct is thus put at issue. And the prisoner who must manage his own litigation is almost hopelessly handicapped. ${ }^{31}$ Indeed, the probability that the proportion of meritorious cases is significantly greater than the statistics indicate suggests that what is needed is to provide more rigorous federal judicial scrutiny rather than to confront the prisoner with new obstacles to relief.

Moreover, the much-advertised burden this class of litigation imposes on federal courts is largely illusory: 660 cases a year, only about 30 of which get

27. Hearings 32 (resolution of 1952 Conference).

28. Circuit Judge Clark, concurring in United States ex rel. Caminito v. Murphy, 222 F.2d 698, 706 (2d Cir. 1955). Circuit Judge Parker has been a consistent critic of prevailing practice. See, e.g., Parker, Limiting the Abuse of Habeas Corpits, 8 F.R.D. 171, 174 (1949), and see note 36 infra and accompanying text.

29. Report of the Habeas Corpus Committee of the Conference of Chief Justices, Aug. 14, 1954, quoted in Hearings 108, 109.

30. H.R. Rep. No. 1200, 84th Cong., 1st Sess. 4 (1955) (hereinafter cited as REpoRT).

31. Cf. Griffin v. Illinois, 24 U.S.L. WeEK 4209 (U.S. April 23, 1956) (denial of equal protection in refusing indigent convicts free trial transcripts in noncapital cases). 
to hearing, ${ }^{32}$ cannot seriously impede the calendars of eighty-six district courts which currently receive 48,000 new civil cases (habeas corpus cases are classified as civil) and 33,000 new criminal cases annually. ${ }^{33}$

The second conclusion-that the framers never contemplated using lower federal courts to review state courts-is unwarranted. Hamilton, in his classic exposition of the character of the proposed federal judicial structure, dealt with the possibility in explicit terms:

"But could an appeal be made to lie from the state courts, to the subordinate federal judicatories?... The only outlines described for [the lower federal courts] are, that they shall be 'inferior to the supreme court,' and that they shall not exceed the specified limits of the federal judiciary. Whether their authority shall be original or appellate, or both, is not declared. All this seems to be left to the discretion of the legislature. And this being the case, I perceive at present no impediment to the establishment of an appeal from the state courts, to the subordinate national tribunals; and many advantages attending the power of doing it may be imagined."34

In any event, as Justice Frankfurter had recent occasion to demonstrate, it is doubtful that habeas corpus jurisdiction can be usefully analogized to appellate review :

"Insofar as this jurisdiction enables federal district courts to entertain claims that State Supreme Courts have denied rights guaranteed by the United States Constitution, it is not a case of a lower court sitting in judgment on a higher court. It is merely one aspect of respecting the Supremacy Clause of the Constitution whereby federal law is higher than State law. It is for the Congress to designate the member in the hierarchy of the federal judiciary to express the higher law. The fact that Congress has authorized district courts to be the organ of the higher law rather than a Court of Appeals, or exclusively this Court, does not mean that it allows a lower court to overrule a higher court. It merely expresses the choice of Congress how the superior authority of federal law should be asserted." 35

Be this as it may, those hostile to existing habeas corpus jurisdiction are persuaded that in all but the most extraordinary circumstances a prisoner in state custody should be confined to Supreme Court review, on certiorari, of the highest state court judgment, whether this be a review of the conviction or of denial of some state collateral remedy. This view was codified in H.R. 5649 , a bill drafted by a Habeas Corpus Committee of the Judicial Conference

32. See text at notes 21 and 24 supra. In a study of twenty-four habeas corpus cases in which hearings were held, Justice Frankfurter found that in two-thirds of the cases the hearing lasted no more than an hour, and that in only one case, which lasted three days, did the hearing last more than four hours. Brown v. Allen, 344 U.S. 443, 514, 529 (1953) (appendix to separate opinion).

33. Director of the Andinistrative Office of the United States Courts, Ann. REP. 1955, at 166, 195 (1956).

34. The Federalist No. 82, at 379 (1842 ed.) (Hamilton).

35. Brown v. Allen, 344 U.S. 443, 510 (1953) (separate opinion). 
of the United States, ${ }^{36}$ and approved, as the House Report observed, by "The Judicial Conference of the United States, composed of the Chief Justice of the United States and the presiding judges of the several courts of appeals, the Conference of Chief Justices of the several States, the Association of States Attorney General, and the section on judicial administration of the American Bar Association. It also has the support and approval of the United States Department of Justice."37

Not too surprisingly, the House Judiciary Committee-despite opposition from the National Association for the Advancement of Colored People, ${ }^{38}$ the American Civil Liberties Union, and a lone judge, Jerome Frank ${ }^{30}$

36. The Committee is composed of Circuit Judges Parker (Chairman), Phillips and Stephens, and District Judges Hooper, Vaught and Wyzanski.

37. REPORT 1.

38. Thurgood Marshall, special counsel for the NAACP, explained in his testimony that the NAACP opposed H.R. 5649 not because it was in any specific sense directed against Negroes but because its total impact would be to "lessen the law's protection of civil rights. ..." Hearings 79 .

In fact, as was noted on the House floor, 102 Cong. REc. 798 (daily ed. Jan. 19, 1956), the bulk of habeas corpus applications are not from the South. Nearly 25 per cent of current applications come from Illinois, Hearings 24, Table 1, which, significantly, has until very recently been plagued with so obscure a system of post-conviction remedies as to invite the censure of the Supreme Court. See Marino v. Ragen, 332 U.S. 561, 563 (1947) (concurring opinion) ; Young v. Ragen, 337 U.S. 235 (1949). Efforts have been made to clarify and simplify these Illinois procedures. See Statement of James C. Murray, Representative from Illinois, Hearings 65; cf. Jennings v. Illinois, 342 U.S. 104 (1951).

39. Judge Frank's extensive concern with problems of remedying lawlessness in state law enforcement is mirrored in opinions such as his ultimately vindicated dissent in United States ex rel. Leyra v. Denno, 208 F.2d 605, 611. (2d Cir. 1953), rev'd, 347 U.S. 556 (1954), and his majority opinion in United States ex rel. Caminito v. Murphy, 222 F.2d 698 (2d Cir.), cert. denied, 350 U.S. $\$ 96$ (1955). His opposition to H.R. 5649 was set forth in a letter (Hearings 16-17) to Congressman Celler, Chairman of the House Judiciary Committee, emphasizing the serious implications of any significant alteration in habeas corpus practice:

“. . . I wish to express a serious objection solely to those provisions of H.R. 5649 which would, except in rare instances, limit review to a petition for certiorari addre'ssed to the United States Supreme Court. My reasons, briefly stated, are as follows:

"1. Experience has shown that the Supreme Court does not now have the time carefully to consider all the many certiorari petitions filed with it. The result of the provisions to which I refer will almost surely be that most efforts to obtain relief will be denied, even when, on careful consideration, it would appear that there has been a deprivation of Federal constitutional rights.

"2. The virtue of the now existing procedure is this: The Federal district court and the Federal court of Appeals have fully canvassed the case before the Supreme Court is asked to pass on it. The opinions of those lower courts greatly aid the Supreme Court in determining whether to grant review.

"The recent case of Leyra v. Denno is illustrative. . . Had the proposed statute been in effect, the Supreme Court would not have had the benefit of the opinions of the lower Federal courts, carefully canvassing the pertinent facts.

"3. It is urged by proponents of the bill that it is unseemly for lower Federal courts to set aside, in effect, judgments of conviction affirmed by the highest State 
reported the bill favorably. ${ }^{40}$ And on January 19, 1956, the bill passed the House without opposition. ${ }^{41}$

Although the bill was not acted on by the Senate prior to the adjournment of the Eighty-fourth Congress, the widespread support it had enlisted suggests that interest in its ultimate enactment will not cease. A summary of the bill and an evaluation of its provisions are therefore in order.

\section{The Proposed Solution: H.R. 5649}

H.R. 5649, if adopted, would have added to Section 2254 of the Judicial Code the following language:

"A Justice of the Supreme Court, a circuit judge or a district court or judge shall entertain an application for a writ of habeas corpus in behalf of a person in custody pursuant to a judgment of a State court, only on a ground which presents a substantial Federal constitutional question (1) which was not theretofore raised and determined, (2) which there was no fair and adequate opportunity theretofore to raise and have determined, and (3) which cannot thereafter be raised and determined in a proceeding in the State court, by an order or judgment subject to review by the Supreme Court of the United States on writ of certiorari.

"An order denying an application for a writ of habeas corpus by a person in custody pursuant to a judgment of a State court shall be reviewable only on a writ of certiorari by the Supreme Court of the United States. The petition for the writ of certiorari shall be filed within thirty days after the entry of such order."

The crux of the bill is the first paragraph. Under that paragraph, habeas corpus could not issue if (a) the prisoner had a prior "fair and adequate op-

courts. The answer is that, whenever a lower Federal court so acts, the State may seek certiorari in the United States Supreme Court, and that, usually, in such circumstances, certiorari is granted.

"4. To save the dignity of the State courts, and yet to meet my objection, the proposed statute might provide that, whenever a petition for certiorari from a State court's decision is presented, the Supreme Court may refer the matter to the appropriate Federal district court to hear and report the facts, and recommend legal conclusions, and that such report shall be reviewed by the appropriate Federal court of appeals before the Supreme Court again considers the case. Such a provision would furnish the Supreme Court with the views of the lower Federal courts.

"Since, however, the existing procedure achieves the same result, I think it would be wiser to retain that procedure...."

Subsequent to the House Judiciary Committee hearings, Circuit Judge Denman expressed his opposition to H.R. 5649. In a Statement and Supplemental Statement filed with the Senate Judiciary Committee in April and May, 1956, Judge Denman noted that H.R. 5649, in conjunction with existing 28 U.S.C. $\$ 1241$ (a), would appear to confer on the Supreme Court the intolerable burden of original jurisdiction, to the exclusion of all other federal courts, over most habeas corpus applications now presented to the district courts. That the Court could exercise original jurisdiction consistently with art. III of the Constitution would seem doubtful in the extreme. Cf. Mooney v. Holohan, 294 U.S. 103 (1935), and note 73 infra.

40. 101 Cong. Rec. 9339 (1955) ; see also Report.

41. 102 ConG. Rec. 797 (daily ed. Jan. 19, 1956). 
portunity" to raise his federal questions in a state proceeding, whether or not he utilized that opportunity, or (b) there is under the state procedure a presently available post-conviction remedy in which the federal questions could be raised and preserved for submission to the Supreme Court on certiorari. ${ }^{42}$

The premise of the bill is that "where adequate procedure is provided by State law for the handling of such petitions, the remedy should be sought in the State courts, with review of State court action only by the Supreme Court of the United States." 43 The legislative purpose was to squeeze the would-be applicant for habeas corpus between the Scylla of implied waiver and the Charybdis of Supreme Court denial of certiorari. There is little open water between the two.

\section{Waiver}

As already indicated, the Judicial Code currently provides that a district court may not entertain an application for habeas corpus unless the applicant has "exhausted the remedies available in the courts of the State." 44 H.R. 5649 would have apparently overlaid this limitation with the further proviso that, where no present state remedy exists, failure to take advantage of a previously available state remedy-at trial, for example-would forever preclude resort to the federal courts.

The proposed rule is grounded in the thought, articulated by the Committee on Habeas Corpus of the Judicial Conference, that "a defendant on trial should not be permitted to play fast and loose with the court in which he is tried by withholding matters which he can bring forward, and then be allowed to raise them in a subsequent proceeding instituted in the Federal Court, without time limitation, and upon new and independent evidence, in the event of a failure to secure a State court judgment in his favor." 45 There can be little criticism of the Committee's point if it really relates only to a deliberate attempt to mousetrap the prosecution. If, for example, a Negro defendant and his attorney knowingly refrained from challenging a discriminatory system of jury selection for the express purpose of injecting into the record a subsequently available federal question, no good reason appears for cloaking the stratagem with the mantle of habeas corpus.

Actually it is hard to suppose that under present practice such a wily defendant would get a very warm reception from the district judge-presumably there is mutuality in the principle "that habeas corpus is . . . to be governed by the rules of fairness enforced in equity." ${ }^{36}$ But, more important, it surpasses

42. The summary contained in the text is thought to be consistent with the explanations given by the Judiciary Committee, and by the Judicial Conference's Habeas Corpus Committee, which drafted the measure. REPORT 3.

43. REPORT 2.

44. 28 U.S.C. $\$ 2254$ (1952) ; see text at notes 17 and 18 supra.

45. REPORT 3.

46. Dissenting opinion of Justice Frankfurter in United States ex rel. Smith v. Baldi, 344 U.S. 561,573 (1953). 
belief that deliberate acquiescence in federal error is a defense practice of any frequency. If the doctrine of implied waiver imported into H.R. 5649 were to cover only such cases, it would be of no consequence.

But it would be a different and very serious matter if the bill, by reversing the strong presumption against inferring waiver of constitutional rights, were to shut off all federal remedies for the prisoner whose trial counsel, in an excess of industrious incompetence, overlooks defects in jury selection or fraud utilized to elicit his client's confession. ${ }^{47}$ The very recently decided case of Darcy $v$. Handy ${ }^{48}$ affords an instructive example.

Darcy v. Handy-like Leyra $v$. Denno, to be considered shortly-is the kind of case whose procedural history Mr. Moody and the Association of State Attorneys General regard as particularly outrageous. Darcy, in a trial severed from that of three co-defendants, was convicted of felony murder in 1948. Certiorari was denied ${ }^{40}$ from the Pennsylvania Supreme Court's affirmance ${ }^{50}$ of the conviction and thereafter was also denied from the state court denial of habeas corpus. ${ }^{\text {11 }}$ Over seven years after the trial, certiorari was granted ${ }^{52}$ to review the Third Circuit's affirmance of denial of habeas corpus, ${ }^{53}$ and finally, on June 11, 1956, the Supreme Court affirmed. ${ }^{54}$ The immediately relevant point, however, is that the issue which the Supreme Court at last considered was not raised in the state court until two years after the state supreme court affirmed Darcy's conviction.

When the Supreme Court considered Darcy's case, it concluded there was no lack of due process in the fact that Judge Boyer, who had presided over and publicly congratulated the jury on the conviction of Darcy's confederates, took it upon himself not only to watch Darcy's trial from a chair right in front of the jury but also on occasion during the trial to confer on the bench with his sitting colleague. Now assume that the Pennsylvania courts had regarded the issue as foreclosed after the initial appeal, and assume further that the Supreme Court had accepted the view of three dissenting justices (and three dissenting circuit judges below) that Judge Boyer had transgressed the bounds of due process. It would seem an extremely rigorous view to conclude that the death sentence nevertheless should remain undisturbed because the "able counsel" who represented Darcy at the first stages of the case had not properly preserved the question. Yet such a ruling may well be within the intended meaning of H.R. 5649. It is possible, of course, that the Supreme Court might neutralize

47. Cf. Adams v. United States ex rel. McCann, 317 U.S. 269 (1942).

48. 24 U.S.L. WEEK 4330 (U.S. June 11, 1956).

49. 338 U.S. 862 (1949).

50. Commonwealth v. Darcy, 362 Pa. 259, 66 A.2d 663 (1949).

51. Commonwealth ex rel. Darcy v. Claudy, $367 \mathrm{~Pa} .130,79$ A.2d 785 (1951), cert. denied, 342 U.S. 837 (1951).

52. 350 U.S. 872 (1955).

53. United States ex rel. Darcy v. Handy, 224 F.2d 504 (3d Cir. 1955), affirming 130 F. Supp. 270 (E.D. Pa. 1954).

54. 24 U.S.L. WeEK 4330 (U.S. June 11, 1956). 
the proposed statutory language, should it ever be adopted, by holding that one whose attorney neglects to preserve substantial constitutional questions has not had the "fair and adequate opportunity" envisaged by the Committee on Habeas Corpus in drafting the bill. But such a holding would not only undercut the notion of waiver-it would verge on the conclusion that the prisoner had been demonstrably denied his constitutional right to counsel.

\section{Denial of Certiorari}

The inarticulate premise of the contention that denial of certiorari should foreclose further federal inquiry is that the Supreme Court is simply not to be believed when it insists that "the denial of a writ of certiorari imports no expression of opinion upon the merits. ..."55

Courts are mysterious institutions, and there is concededly no available subjective test of the Supreme Court's sincerity. In this instance there is, however, an available objective test. The history of Leyra v. Denno, ${ }^{50}$ which Mr. Moody and his fellow state prosecutors regard as among "the most significant"57 of the cases they rely on, plainly demonstrates that in the field of habeas corpus the Court's Delphic pronouncements about the implications of a denial of certiorari mean precisely what they say.

In 1950, Camilo Leyra, a middle-aged bartender, was indicted and tried for the first degree murder of his aged parents. Admitted in evidence against him were confessions made to a police psychiatrist and, soon thereafter, to others. On appeal from the death sentence, the New York Court of Appeals reversed, holding that the confession to the psychiatrist had been elicited by "torture of the mind."'5s On the second trial, the other confessions were again admitted: the death sentence was affirmed by the New York Court of Appeals, over the objection that the subsequent confessions flowed from and were infected by the first one. ${ }^{59}$ The Supreme Court denied certiorari. ${ }^{60}$ Leyra sought habeas corpus in the federal district court. Denial of the writ ${ }^{61}$ was affirmed by a divided Second Circuit. ${ }^{62}$ The Supreme Court granted certiorari, ${ }^{63}$ concluded that the subsequent confessions were likewise invalid, and reversed. ${ }^{64} \mathrm{New}$ York then tried, convicted and sentenced Leyra to death for a third time. But this time the New York Court of Appeals reversed the conviction and ordered the indictment dismissed, concluding that "the prosecution has produced not a single

55. United States v. Carver, 260 U.S. 482, 490 (1923).

56. 347 U.S. 556 (1954).

57. See text at note 1 supra.

58. People v. Leyra, 302 N.Y. 353, 364, 98 N.E.2d 553, 559 (1951).

59. People v. Leyra, 304 N.Y. 468,108 N.E.2d 673 (1952).

60. Leyra v. New York, 345 U.S. 918 (1953).

61. Leyra v. Denno, 113 F. Supp. 556 (S.D.N.Y. 1953).

62. United States ex rel. Leyra v. Denno, 208 F.2d 605 (2d Cir. 1953).

63. Leyra v. Denno, 347 U.S. 926 (1954).

64. Leyra v. Denno, 347 U.S. 556 (1954). 
trustworthy bit of affirmative, independent evidence connecting defendant with the crime...."65

On April 27, 1956, after four years, eight months and thirty-one days in the death house, Camilo Leyra was freed. ${ }^{60}$ Under H.R. 5649 he would have been dead long since.

Because the accused was ultimately discharged from custody, the path the Leyra case took is peculiarly dramatic. But it is not unique. There are other cases whose merits the Court has examined on the second trip after refusing to review the issues when first presented. ${ }^{67}$ Plainly, therefore, denial of certiorari cannot be equated with a Supreme Court determination that no substantial federal question is presented.

This might seem to mean that the Court's disposition of certiorari petitions is a hopelessly quixotic affair, that the discretion given the Court is misplaced, and that the Court should henceforth be properly required, by legislation like H.R. 5649, to determine certiorari petitions in state criminal cases as if it were disposing of the cases on the merits. The diagnosis and the prescription have surface plausibility, but no more.

There may be many reasons why a particular Justice votes to deny certiorari, and these reasons doubtless cannot be canvassed in full without participating in the secret conferences of the Court. But some factors affecting certiorari practice-particularly the factors operating in state criminal cases-are matters of public knowledge; and they do not add up to judicial irresponsibility.

In the first place, no matter how worthy a case may look to lawyers unfamiliar with the record-or to the lawyer who made the record and is dazzled with his eloquence in a losing cause-the Supreme Court has no jurisdiction if federal questions are not properly raised or if the state court disposes of the case on a state ground.

Secondly, "experience has shown that the Supreme Court does not now have the time carefully to consider all the many certiorari petitions filed with it." 68 The Court has little enough time to devote to well drafted petitions. But hundreds of the certiorari petitions filed annually in the criminal field are prepared by the prisoners themselves, without benefit of counsel. Under these circumstances, untangling the jurisdictional facts and assessing the substantiality of the questions sought to be presented is frequently an enormous task.

65. People v. Leyra, 1 N.Y.2d 199, 210, 134 N.E.2d 475, 481 (1956).

66. N.Y. Times, April 28, 1956, p. 29, col. 3.

67. See United States ex rel. Smith v. Baldi, 344 U.S. 561 (1953) ; Brown v. Allen, 344 U.S. 443 (1953) ; Moore v. Dempsey, 261 U.S. 86 (1923) ; Frank v. Mangum, 237 U.S. 309 (1915). Cf. United States ex rel. Caminito v. Murphy, 222 F.2d 698 (2d Cir. 1955), ccrt. denicd, 350 U.S. 896 (1956) (denial of certiorari to review state court conviction, followed by denial of habeas corpus reversed by court of appeals, certiorari being again denied); Cranor v. Gonzales, 226 F.2d S3 (9th Cir. 1955) (affirming grant of federal habeas corpus after denial of certiorari to review denial of state habeas corpus); United States ex rel. Rogers v. Cummings, Civil No. 6294, D. Conn., Sept. 19, 1956 (memorandum filed, granting habeas corpus after denial of certiorari to review state court conviction).

68. Letter from Judge Frank to Congressman Celler, note 39 supra. 
To legislate on the theory that denials of such certiorari petitions are determinations on the merits is to do justice neither to the Supreme Court nor to the prisoner-petitioners. Justice Frankfurter, in explaining why district court judges entertaining habeas corpus petitions should not draw inferences adverse to the petitioners from prior denials of certiorari, has sought to make this plain:

"We have repeatedly indicated that a denial of certiorari means only that, for one reason or another which is seldom disclosed, and not infrequently for conflicting reasons which may have nothing to do with the merits and certainly may have nothing to do with any view of the merits taken by a majority of the Court, there were not four members of the Court who thought the case should be heard. Any departure from this fundamental rule in the type of case we are considering ought to be based on a showing that these denials of certiorari, unlike all the other denials, are in fact the essential equivalents of adjudication on the merits. . . . There is certainly no more assurance that these petitions have been canvassed on their merits than is true of cases within the ordinary domain of certiorari jurisdiction.

"Indeed, there is less assurance that petitions by State prisoners could be considered on their merits than is the case with ordinary petitions for certiorari." 69

Manifestly, H.R. 5649 rests on a faulty analysis of the significance of the Court's denial of certiorari. The nature of the error suggests that it is the members of the Supreme Court, more than any other members of the federal and state judiciaries, whose insight into the problems of habeas corpus practice would be most relevant. Regrettably, the Justices had little to do with framing the bill. ${ }^{70}$ Doubtless the bill's inadequacies are traceable in large

69. Separate opinion in Brown v. Allen, 344 U.S. 443, 492 (1953). The Justice goes on to say:

"These petitions for certiorari are rarely drawn by lawyers; some are almost unintelligible and certainly do not present a clear statement of issues necessary for our understanding, in view of the pressure of the Court's work. The certified records we have in the run of certiorari cases to assist understanding are almost unknown in this field. Indeed, the number of cases in which most of the papers necessary to prove what happened in the State proceedings are not filed is striking. Whether there has been an adjudication or simply a perfunctory denial of a claim below is rarely ascertainable. Seldom do we have enough on which to base a solid conclusion as to the adequacy of the State adjudication. Even if we are told something about a trial of the claims the applicant asserts, we almost never have a transcript of these proceedings to assist us in determining whether the trial was adequate. Equally unsatisfactory as a means for evaluating the State proceedings is the filing of opinions; in less than one-fourth of the cases is more than a perfunctory order of the State courts filed. We would have to have very different records and to alter our consideration of these cases radically if a denial could fairly be deemed to be an undisclosed decision on the merits. In a few cases the issues before the District Court had not even been raised here. In other cases, the emphasis put on the issues here differed considerably from that put on them in the District Courts. ..."

Ibid.

70. It would seem quite unwarranted to infer Supreme Court concurrence in H.R. 5649 from the fact that Chief Justice Warren presided over sessions of the Judicial Con- 
measure to fundamental misunderstanding of the role that is and can be played by the Supreme Court in reviewing state and federal adjudications. ${ }^{71}$

\section{Conceuston}

One might reasonably expect that an inquiry into proposed curtailment of habeas corpus would start with the Constitution. That document, after all, provides explicitly that "the privilege of the Writ of Habeas Corpus shall not be suspended, unless when in Cases of Rebellion or Invasion the public Safety may require it." 22 But it is conventionally assumed that perpetuation of federal district court habeas corpus jurisdiction is not constitutionally required, on the theory that Congress is free to give what items of federal jurisdiction it chooses to courts which, unlike the Supreme Court, exist only by congressional sufferance. ${ }^{73}$ Moreover, the pending bill does not by its terms eliminate federal habeas

ference endorsing the bill; nothing in the statutory provision establishing the Judicial Conference imposes on the Chief Justice the duty of representing the Supreme Court in the deliberations of the Conference. 28 U.S.C. $\$ 331$ (1952). Scrutiny of recent opinions of Justices Frankfurter and Black strongly suggests that at least they and Justice Douglas would be unsympathetic with the proposal. See Brown v. Allen, 344 U.S. 443, 498-99, 508-09, 511-13, 553-54 (1953).

71. H.R. 5649, if enacted, will mean that denial of certiorari from a state court will bar any further federal challenge based on the questions sought to be raised in the certiorari petition. The impact this will have on the task of passing on certiorari petitions, outlined by Justice Frankfurter in the language quoted in the text, at note 69 supra, can only be conjectured. But it should be noted that many certiorari petitions the Court might wish to grant are beyond its jurisdictional reach because the federal questions apparently presented were not adequately raised-or not disposed of on federal grounds-in the state courts. It cannot be presumed to have been the intent of the framers of H.R. 5649 to bar future federal challenge where the objections to the petition for certiorari are jurisdictional (such a construction might, indeed, exacerbate questions as to the validity of H.R. 5649). There is, in any event, no way of telling from an order denying certiorari whether some or any of the Justices voted to deny the writ because they were skeptical of the petition's jurisdictional sufficiency.

The added burden in reviewing certiorari petitions from state courts which H.R. 5649 would probably impose would only be aggravated by the provisions of the second paragraph of H.R. 5649, under which federal district court dispositions of habeas corpus petitions would go directly to the Supreme Court on certiorari. Seventy appeals in habeas corpus cases were filed in the federal courts of appeals in fiscal year 1955. DIRECTOR OF THE Administrative Office of the United States Courts, Ann. Rep. 1955, at 160 (1956).

72. U.S. ConsT. art. I, $\$ 9, \mathrm{cl} .2$.

73. See Ex parte Bollman, S U.S. (4 Cranch.) $* 74, * 95$ (1807); Sheldon v. Sill, 49 U.S. (8 How.) $* 441$ (1850); Ex parte McCardle, 74 U.S. (7 Wall.) 506 (1868). If the theory is sound, Congress, without "suspending" the privilege, can nevertheless nullify it by simply withholding all habeas corpus jurisdiction from all federal courts: Congress may not only give lower federal courts none, some or all of the powers reserved to them in art. III of the Constitution; Congress can also limit or abolish the Supreme Court's appellate jurisdiction, $c f$. Ex parte McCardle, supra, and the unalterable original jurisdiction of the Supreme Court probably would provide small scope for the writ of habeas corpus, for federal or state prisoners. See Ex parte Dort, 44 U.S. (3 How.) *103 (1845); Ex parte Bollman, supra; cf. Marbury v. Madison, 5 U.S. (1 Cranch.) $* 137$ (1803). 
corpus for state prisoners; the remedy allegedly retains its vitality where no other avenue of judicial relief was or is open. ${ }^{74}$ Finally, it is of course true that until 1867 there was no federal habeas corpus for prisoners in state custody. ${ }^{75}$ From this it may be thought to follow that the constitutional grant of the privilege did not contemplate-or at all events did not require-an available collateral remedy for state prisoners. Nor is it likely that the Court would presently accept the rather elaborate argument that the Fourteenth Amendment retroactively inflated the scope of the constitutional privilege to include the newly created federal rights to protection against state action.

But "what is constitutional may still be very unwise." 6

$W$ isdom here dictates other needs and other solutions. What is needed is expert and painstaking judicial scrutiny, which can weigh on sensitive scales the competing claims of individual liberty and state law enforcement. In order to do the job with even greater care than is now exercised-and perhaps with greater deference to the dignity owing a sovereign state's judicial processespresent federal habeas corpus jurisdiction might fittingly be transferred to a special three-judge Court of Habeas Corpus. ${ }^{77}$

Such a reform would meet the real problem-vindication of fundamental constitutional rights in a manner consistent with American federalism. But proposals like H.R. 5649 would ride rough-shod over those rights, and over the proud boast that "the great writ of habeas corpus, has been for centuries esteemed the best and only sufficient defence of human freedom."78

In short, adoption of restrictive legislation of the character proposed would be "a tragic retreat."79 For, aside from the limited supervisory role the Supreme Court can play, such legislation would effectively confine the policing of the Fourteenth Amendment's mandates to the courts of the several states. And, "unfortunately, instances are not wanting in which even the highest state courts have failed to recognize violations of these precepts that offend the limitations which the Constitution of the United States places upon enforcement by the States of their criminal law." that state trial judges can, in appropriate post-conviction proceedings, correct the errors of brethren of equal or higher rank..$^{81}$ The understandable reluctance

74. Compare United States v. Hayman, 342 U.S. 205 (1952).

75. See, e.g., Ex parte Dort, 44 U.S. (3 How.) $* 103$ (1845), and see, generally, Collings, Habeas Corpus for Convicts-Constitutional Right or Legislative Grace?, 40 CALIF. L. REv. 335, 350-51. (1952).

76. See Chafee, The Blessings of Liberty 89 (1956).

77. A similar proposal was advanced and later abandoned by the Judicial Conference. See Brown v. Allen, 344 U.S. 443, 499 (1953) (separate opinion).

78. Ex parte Yerger, 75 U.S. (8 Wall.) 85, 95 (1868).

79. Don't Retreat on Civil Rights, editorial in The Milwaukee Journal, July 7, 1956, p. 8, cols. 1-2, opposing enactment of H.R. 5649 .

80. Brown v. Allen, 344 U.S. 443, 511 (1953) (separate opinion of Justice Frankfurter).

81. See, e.g., the confidence expressed by Circuit Judge Parker and by Ohio's Chief Justice Weygandt in the availability of state collateral remedies as an effective alternative to the present scope of federal habeas corpus. Hearings 11, 14. 
of judges to impeach their colleagues, or to flout the will of juries and the electorate as a whole, ${ }^{\mathbf{s 2}}$ together with the procedural complexities that becloud most post-conviction remedies, ${ }^{83}$ would appear to explain the striking dearth of state court decisions sustaining collateral attacks upon criminal convictions.

Those who advocate curtailment of the writ lay special emphasis upon the asserted need for judicial finality: at some point, it is urged, there must be an end to litigation. As a general proposition there is, of course, much to be said for the procedural devices which limit the suitor to his day in court and his right of appeal. But the manifest utility within their proper sphere, of res judicata, collateral estoppel, and the rest of that unfriendly but expeditious tribe, should not so dazzle the beholder as to stimulate their application outside that sphere. These concepts, like stare decisis, stem from the principle that "in most matters it is more important that the applicable rule ... be settled than that it be settled right." Ba But where personal liberty is involved, a democratic society employs a different arithmetic and insists that it is less important to reach an unshakable decision than to do justice. It is for this reason that, as Justice Frankfurter has put it, "the uniqueness of habeas corpus in the procedural armory of our law cannot be too often emphasized."85 The habeas corpus writ "is in the spirit of our inherited law. It accords with, and is thoroughly regardful of, 'the liberty of the subject,' from which flows the right in England to go from judge to judge, any one of whose decisions to discharge the prisoner is final." 86 Federal habeas corpus procedure does notand very likely should not-emulate the extraordinary liberality of the English rule. ${ }^{87}$ But, as Justice Rutledge once observed, "the writ should be available whenever there clearly has been a fundamental miscarriage of justice for which no other adequate remedy is presently available. Beside executing its great object, which is the preservation of personal liberty and assurance against its wrongful deprivation, considerations of economy of judicial time and procedures, important as they undoubtedly are, become comparatively insignificant."8s

82. It would seem fair to suppose, for example, that in many Southern or border states an elected judge who ordered the retrial or release of a Negro prisoner would be jeopardizing his career. See Statennent by Circuit Judge Denman, supra note 39, at 5-10.

83. "As a result, masy claims of denial of federal right, when sought after conviction, are cognizable in state courts only with difficulty, or not at all." Note, Effect of the Federal Constitution in Requiring Siate Post-Conviction Remedies, 53 CoLun. L. REv. 1143, 1145 (1953). See note 38 supra.

84. Burnet v. Coronado Oil \& Gas Co., 285 U.S. 393, 406 (1932) (dissenting opinion of Justice Brandeis).

85. Brown v. Allen, 344 U.S. 443, 512 (1953) (separate opinion).

86. Id. at 509.

87. See ibid.

SS. Sunal v. Large, 332 U.S. 174, 189 (1947) (dissenting opinion). In Wade v. Mayo, 334 U.S. 672,681 (1948), the Court, through Justice Murphy, observed that, "the prevention of undue restraints on liberty is more important than mechanical and unrealistic administration of the federal courts." 
The articulate premises of the attack on the habeas corpus writ are grounded in the supposed first principles of judicial finality and of the sound management of a federal union. Just below the surface, however, lurks the less plainly articulated but perhaps more deeply felt belief that the Supreme Court has grievously erred in the sequence of great cases which utilized habas corpus to probe trial records for fundamental error. ${ }^{89}$ Somewhat circuitously the suggestion is deftly made that the real onus for current "abuse" of habeas corpus must rest with those Justices who insistently and ceaselessly require that state trial procedures conform with the mandates of the Fourteenth Amendment. ${ }^{90}$

If the Court has been too vigilant, curtailing habeas corpus would do much to redress the balance. But those who see in these great cases judicial statesmanship of a high order-slowly educating the bench, the bar, police, prosecutors and the mass of citizens to the highest traditions of Anglo-American lawshould look sceptically at attempts to circumvent the writ. Justice Black has put the matter simply and well: "[I]t is never too late for courts in habeas corpus proceedings to look straight through procedural screens in order to prevent forfeiture of life or liberty in flagrant defiance of the Constitution. . . . Perhaps there is no more exalted judicial function."91

89. See, e.g., cases cited in notes $11-16$, supra.

90. See, e.g., Hearings 3, 12-13, 42-44; REPORT 2.

91. Brown v. Allen, 344 U.S. 443, 554 (1953) (dissenting opinion). 


\section{THE YALE LAW JOURNAL}

ROBERT W. BLANCHETTE

Editor-in-Chief

Arthur L. Liman

STEPHEN A. WeIner

Camment Editors

Matthew T. Adazis

MaLvin E. BANK

JoHN W. Barnuar

ThOMas D. BarR

Robert T. Basseches

C. William Berger

Frederick L. Bernstein

NeIL N. BERNSTEIN

David P. Bicks

Judith Míra Bleich

Newton D. Brenner

MalColM R. Busch

Guido Calabresi

Laura M. Chapman

Paul H. DeCoster

Axer H. Baum

Managing Editor

Robert J. DeI Tufo

Milton P. DeVane

JOHN RICHARD DUfFIELD

ARTHUR FleisCHER, JR.

Gerald T. Flom

SETH E. Frank

Victor S. Friednan

Morton I. Greenberg

Alan M. Hofrman

William E. Huth

LLOYD J. KENO

David KuINgsberg

HaRoLd S. LEVY

IRWIN A. LEVY

Julius LEwIS
H. E. DunKeIbERGER, JR.

Article and Book Review Editor

RODNEY E. Eyster

Alvin Friedaran

Note Editors

Richard Marin

RICHARD M. MEYER

Hugh G. MoultoN

WALter W. OberReit

Richard W. Pendleton, JR.

Burton RafFel.

ROBERT S. REDMOUNT

JEROME HowarD REICHMAN

Richard J. SExton

Jerrold L. Morgulas

STEPHEN N. SHulMaN

LEwIS A. STERN

Charles W. Thomasson

Stanley E. Tobin

FRANK E. G. WETL.

ROBERT L. WeINBERG

Marie McMamon

Business Secretary

Citations conform with $A$ Uniform System of Citations (9th ed. 1955), copyright by the Columbia, Harzard, and University of Pennsylvania Law Reviezws and the Yale Law Journal. 


\section{CONTRIBUTORS TO THIS ISSUE}

FREDERICK M. Rowe. B.B.A. 1949, C.C.N.Y.; LL.B. 1952, Yale University. Former law clerk to Mr. Justice Tom C. Clark. Conferee for Antitrust Policy in Distribution, Attorney General's National Committee to Study the Antitrust Laws, 1953-55. Member of the District of Columbia and New York Bars.

Lours H. Pollak. B.A. 1943, Harvard University ; LL.B. 1948, Yale University. Associate Professor of Law, Yale Law School. Former law clerk to the late Mr. Justice Wiley Rutledge. Member of the Connecticut and New York Bars.

Flening JAmes, JR. B.A. 1925, LL.B. 1928, Yale University. Lafayette S. Foster Professor of Law, Yale Law School. Member of the Connecticut Bar.

David W. LouiselL. B.S.L. 1935, LL.B. 1938, University of Minnesota. Professor of Law, University of California, Berkeley. Member of the Minnesota, New York and District of Columbia Bars. 
HeinOnline -- 66 Yale L.J. [i] 1956-1957 


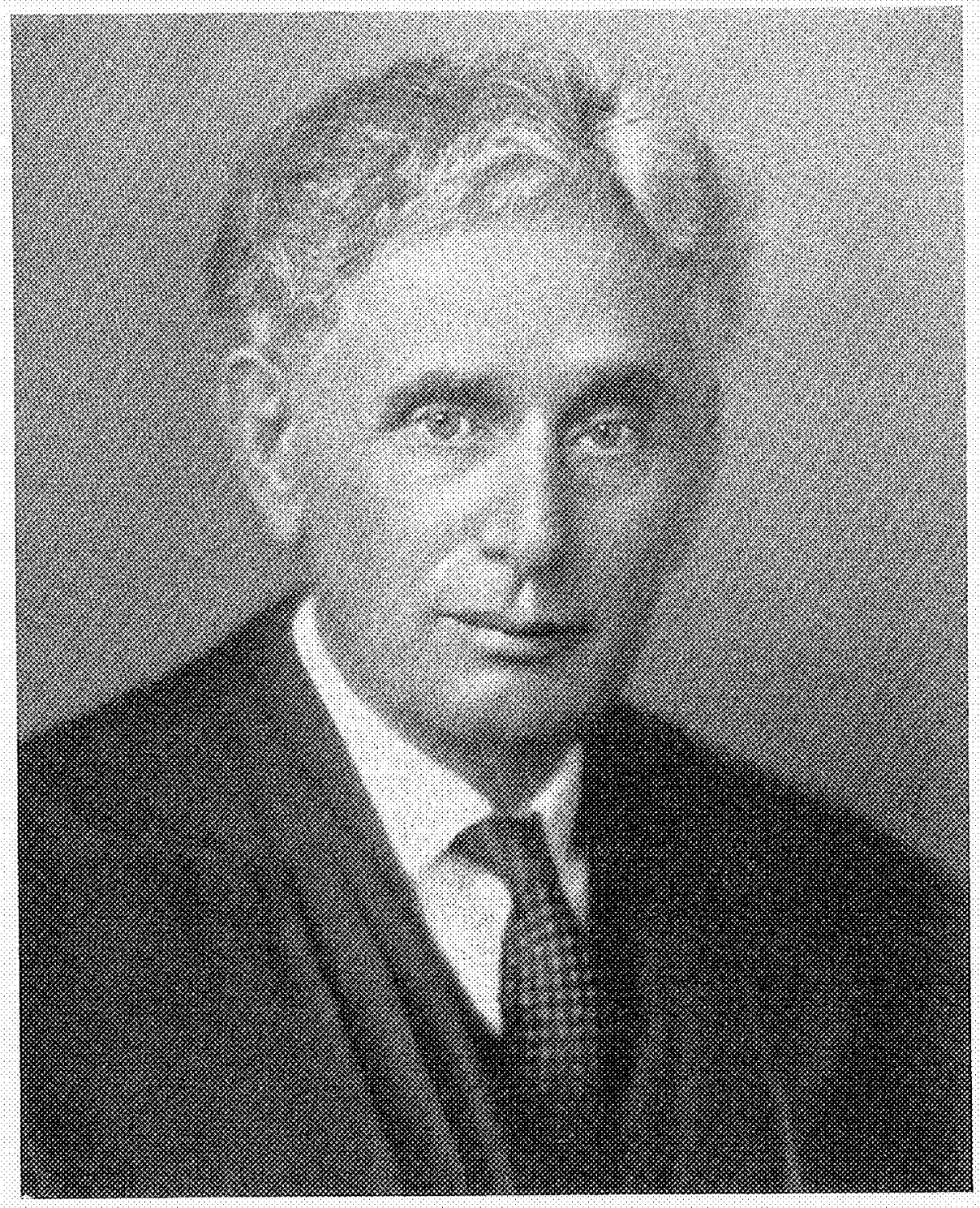

Honrs b Ewong

IOUIS DFMBITZ BRANDEIS

$1856-1941$ 